\title{
Coupled climate model simulation of Holocene cooling events: oceanic feedback amplifies solar forcing
}

\author{
H. Renssen ${ }^{1}$, H. Goosse ${ }^{2}$, and R. Muscheler ${ }^{3}$ \\ ${ }^{1}$ Faculty of Earth and Life Sciences, Vrije Univ. Amsterdam, De Boelelaan 1085, 1081 HV Amsterdam, The Netherlands \\ ${ }^{2}$ Institut d'Astronomie et de Géophysique G. Lemaître, Univ. Catholique de Louvain, 2 Chemin du Cyclotron, 1348 \\ Louvain-la-Neuve, Belgium \\ ${ }^{3}$ NASA/Goddard Space Flight Center, Climate \& Radiation Branch, Greenbelt, MD 20771, USA
}

Received: 10 March 2006 - Published in Clim. Past Discuss.: 24 May 2006

Revised: 20 July 2006 - Accepted: 4 September 2006 - Published: 13 September 2006

\begin{abstract}
The coupled global atmosphere-ocean-vegetation model ECBilt-CLIO-VECODE is used to perform transient simulations of the last 9000 years, forced by variations in orbital parameters, atmospheric greenhouse gas concentrations and total solar irradiance (TSI). The objective is to study the impact of decadal-to-centennial scale TSI variations on Holocene climate variability. The simulations show that negative TSI anomalies increase the probability of temporary relocations of the site with deepwater formation in the Nordic Seas, causing an expansion of sea ice that produces additional cooling. The consequence is a characteristic climatic anomaly pattern with cooling over most of the North Atlantic region that is consistent with proxy evidence for Holocene cold phases. Our results thus suggest that the ocean is able to play an important role in amplifying centennial-scale climate variability.
\end{abstract}

\section{Introduction}

Centennial-scale climatic anomalies that occurred in the North Atlantic region during the last 11500 years have been registered in a variety of paleoclimatic archives, such as marine sediments (e.g., Bond et al., 2001), lake level data (e.g., Magny, 1993; Holzhauser et al., 2004) and glacier records (e.g., Denton and Karlén, 1973; Holzhauser et al., 2004). For instance, analyses of marine sediments have revealed the presence of enhanced concentrations of ice-rafted debris (IRD) around 11.1, 10.3, 9.4, 8.1, 5.9, 4.2, 2.8, 1.4 and $0.4 \mathrm{ka}$ BP, probably due to southward and eastward advection of cooler surface waters in the subpolar North Atlantic (Bond et al., 2001). The timing of these IRD events corre-

Correspondence to: H. Renssen

(hans.renssen@geo.falw.vu.nl) lates with periods of reduced solar activity as reconstructed using cosmogenic isotopes (Bond et al., 2001), suggesting a confirmation of the solar-climate link proposed earlier by Denton and Karlén (1973) and Magny (1993) for centennial time-scale variability during the Holocene. This solarclimate link, however, has been debated because solar irradiance changes are assumed to be relatively small and an amplifying mechanism is required (e.g., Rind, 2002) to account for the magnitude of the observed climate changes $(0.5$ to $1{ }^{\circ} \mathrm{C}$ in Europe during the last 500 years, e.g., Luterbacher et al., 2004) that have been, at least partly, attributed to solar activity reductions.

Numerical climate models have been used extensively to study the impact of solar forcing on climate (e.g., Cubasch et al., 1997; Bertrand et al., 1999; Rind et al., 1999; Shindell et al., 2001), with most studies focusing on the well-known Maunder sunspot minimum ( 1650-1700 AD, Eddy, 1976). Simulations performed by Shindell et al. (2001), for example, suggest that reduced total solar irradiance (TSI) during the Maunder Minimum could have resulted in changes in atmospheric circulation that enhanced the cooling over the Northern Hemisphere continents. In addition, several model studies have indicated that TSI variations could modify the behaviour of the oceanic circulation (e.g., Cubasch et al., 1997; Goosse et al., 2002; Weber et al., 2004).

Up to now, a realistic TSI reconstruction for the entire Holocene has not become available, thus hampering the execution of model studies to explore the solar-climate link on longer time-scales. However, recent analyses of the ${ }^{14} \mathrm{C}$ production rate and ice core ${ }^{10} \mathrm{Be}$ records (Muscheler et al., 2004a, 2005; Vonmoos et al., 2006), now permits us to construct improved and more realistic estimates of TSI variations covering the last 9000 years. This has enabled us to perform transient simulations of the last 9000 years with a coupled

Published by Copernicus GmbH on behalf of the European Geosciences Union. 


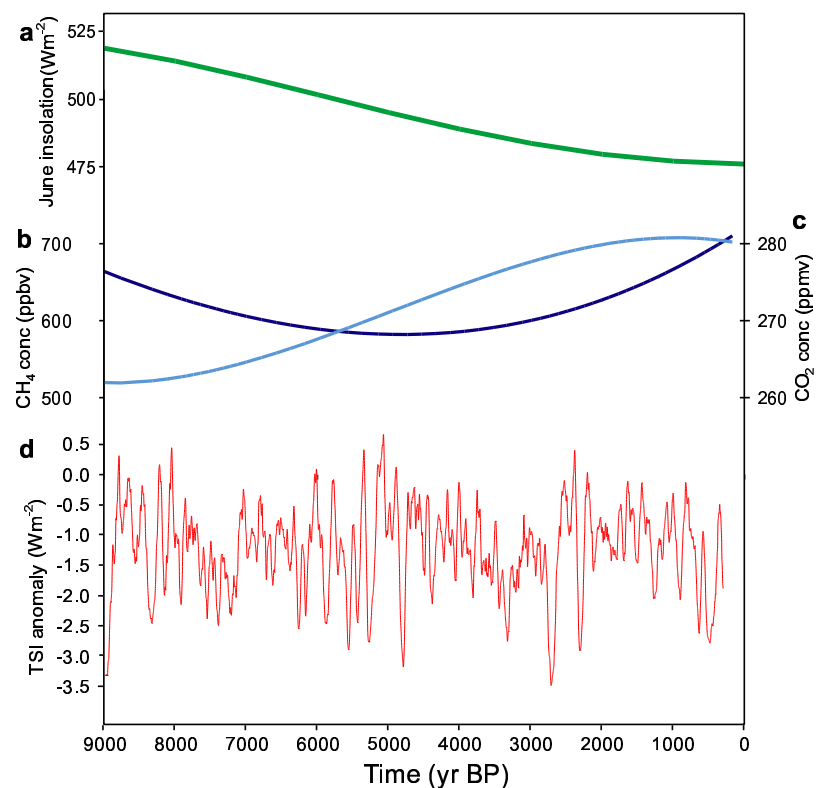

Fig. 1. Forcings applied in the simulation experiments: (a) insolation related to orbital forcing (Berger, 1978), shown here is the example of June insolation at $60^{\circ} \mathrm{N}$, (b-c) smoothed long-term atmospheric concentrations of $\mathrm{CH}_{4}$ (dark blue, b) and $\mathrm{CO}_{2}$ (light blue, c) based on ice-core records (Raynaud et al., 2000), and (d) TSI anomalies based on ${ }^{14} \mathrm{C}$ (see text).

climate model to study the potential impact of TSI variations on the Holocene climate. The objective of this paper is to investigate to what extent our model's response to these TSI variations can explain the centennial-scale Holocene cooling events registered in proxy records.

\section{Model and experimental design}

We present results using version 3 of the ECBilt-CLIOVECODE global climate model, consisting of three main components describing the coupled atmosphere-oceanvegetation system in three dimensions. The atmospheric component ECBilt is a quasi-geostrophic model with T21 horizontal resolution (about $5.6^{\circ}$ latitude $\times 5.6^{\circ}$ longitude) and 3 levels (Opsteegh et al., 1998). ECBilt contains a full hydrological cycle, including a simple model for soil moisture over continents, and computes synoptic variability associated with weather patterns. Cloud cover is prescribed according to modern climatology. The oceanic component CLIO consists of a primitive-equation, freesurface ocean general circulation model (OGCM) coupled to a thermodynamic-dynamic sea-ice model (Goosse and Fichefet, 1999). The OGCM has a $3^{\circ}$ latitude $\times 3^{\circ}$ longitude resolution and 20 unevenly spaced levels, while the sea ice model has 3 layers. It should be noted that, compared to comprehensive coupled GCMs, the simulation of the surface ocean dynamics (including sea ice and deep convection) in
CLIO might be affected by the relatively simple calculation of atmospheric surface variables in ECBilt (see Opsteegh et al., 1998). Unfortunately, we have not been able to quantify this effect. However, we assume that this effect on our results is minor, as the modern surface climate in the Arctic simulated by ECBilt-CLIO is reasonable (Goosse et al., 2001) and the sensibility of the meridional overturning circulation is within the range of GCMs. ECBilt-CLIO has been coupled to VECODE (Brovkin et al., 2002), a model that describes the dynamics of two vegetation types (grassland and forest) and a third dummy type (bare soil).

The sensitivity of ECBilt-CLIO-VECODE to a doubling of atmospheric $\mathrm{CO}_{2}$ concentration is $1.8^{\circ} \mathrm{C}$ at equilibrium, which is in the lower range of coupled climate models. Furthermore, the maximum overturning streamfunction in the North Atlantic Ocean was reduced by $15 \%$ compared to a control simulation at the time of $\mathrm{CO}_{2}$ doubling in an experiment in which the $\mathrm{CO}_{2}$ concentration is increased by $1 \%$ per year, which is in that case well in the range of other models (Gregory et al., 2005). Different versions of the model have successfully been used for simulation studies on a variety of topics, including the impact of freshwater perturbations (Renssen et al., 2001, 2002; Wiersma and Renssen, 2006), solar forcing of climate change (Goosse et al., 2002; van der Schrier et al., 2002; Goosse and Renssen, 2004; Weber et al., 2004), the climate of the last millennium (Goosse et al., 2004; Goosse et al., 2005a, b) and future climate evolution (Schaeffer et al., 2002, 2005). Further details about the ECBilt-CLIO-VECODE model and the difference between model versions are available at http://www.knmi.nl/onderzk/ CKO/ecbilt.html.

We performed a 5-member ensemble simulation forced by time-varying forcings for the last 9000 years: orbital forcing (Berger, 1978), atmospheric trace gas concentrations (Raynaud et al., 2000) and TSI variations (Figs. 1a-d). The applied orbital and greenhouse gas forcing is identical to that used by Renssen et al. (2005a, b), while the TSI forcing timeseries were newly constructed for this study. The ensemble members differ only in their initial conditions, which were derived from a multimillennial equilibrium experiment with constant forcings for $9000 \mathrm{yr}$ BP.

TSI variations are prescribed as an anomaly of the solar constant (i.e., $1365 \mathrm{Wm}^{-2}$, maximum negative anomaly is $-3.5 \mathrm{Wm}^{-2}$ ) and are based on the ${ }^{14} \mathrm{C}$ production rate derived from the tree-ring $\Delta^{14} \mathrm{C}$ record (Stuiver et al., 1998; Muscheler et al., 2005). To correct for the non-linear relationship between solar magnetic shielding, geomagnetic dipole field intensity and ${ }^{14} \mathrm{C}$ production rate we used model results (Masarik and Beer, 1999) to infer the solar modulation function that parameterises the galactic cosmic ray deflection due to the solar wind. The ${ }^{14} \mathrm{C}$ production rate was reconstructed under the assumption of a constant carbon cycle (Muscheler et al., 2005). Especially on the decadal to centennial time scales, which are of interest in our analysis, the potential for carbon cycle induced changes in $\Delta^{14} \mathrm{C}$ is 
not very large (e.g., Muscheler et al., 2004b). In addition, the agreement between ${ }^{14} \mathrm{C}$ production rate and ${ }^{10} \mathrm{Be}$ measured in ice cores on these time scales gives us confidence that we are able to isolate the production signal induced by the variable sun (Muscheler et al., 2004a; Vonmoos et al., 2006). On millennial time scales, however, potential changes in solar activity are not well constrained. ${ }^{10} \mathrm{Be}$ from Summit, Greenland, indicates different long-term changes compared to the ${ }^{14} \mathrm{C}$ production rate (Muscheler et al., 2005; Vonmoos et al., 2006). This might be due to changes in the carbon cycle or in the atmospheric ${ }^{10} \mathrm{Be}$ transport and deposition onto ice sheets. In addition, within the relatively large uncertainties of the geomagnetic field reconstructions (Yang et al., 2000; Muscheler et al., 2005), the long-term changes in the ${ }^{14} \mathrm{C}$ production rate can be explained by geomagnetic field changes. Therefore, due to the uncertainties connected to the data, long-term changes in solar activity cannot be yet inferred with this method. To avoid introducing an artificial trend in our solar forcing record, we removed the long-term trend in the solar modulation parameter by subtracting a 5th order polynomial fitted to the data.

To obtain TSI variations we assumed that the solar modulation parameter scales linearly to the variations in total solar irradiance. Maunder minimum type solar minima are assumed to represent a TSI reduction of $2.6 \mathrm{Wm}^{-2}$ (or $0.2 \%$ ) based on Lean (2000). The last two assumptions introduce the largest uncertainties in our irradiance record. For instance, Lean et al. (2002) and Fröhlich and Lean (2004) suggest a TSI reduction of $0.08 \%$ for the Maunder Minimum compared to the 11-yr TSI average during recent satellitebased measurements, which is considerably lower than the value we have applied. However, Fröhlich and Lean (2004) acknowledge that a lack of physical understanding precludes definitive historical irradiance estimates. Therefore, we think that our record is a first and reasonable step to quantitatively study the potential solar influence on climate on longer time scales. To reduce the short-term noise in the forcing TSI series, we applied a 55-yr running mean filter (Fig. 1d).

\section{Results and discussion}

\subsection{Global climate response to TSI variations}

The ensemble-mean result for the global surface temperature (Fig. 2a) represents the system's forced response, as the averaging strongly reduces the internal variability (e.g., Goosse et al., 2005). The simulated ensemble-mean long-term cooling trend in annual global surface temperature (from $15.95^{\circ} \mathrm{C}$ to $15.65^{\circ} \mathrm{C}$ ) is associated with the orbital forcing. Earlier experiments with the same model showed that the millennial-scale annual temperature evolution closely follows the decreasing orbitally-forced insolation trends in particular seasons, i.e. June-July in the Northern Hemisphere (Renssen et al., 2005a) and September-October in the Southern Hemisphere
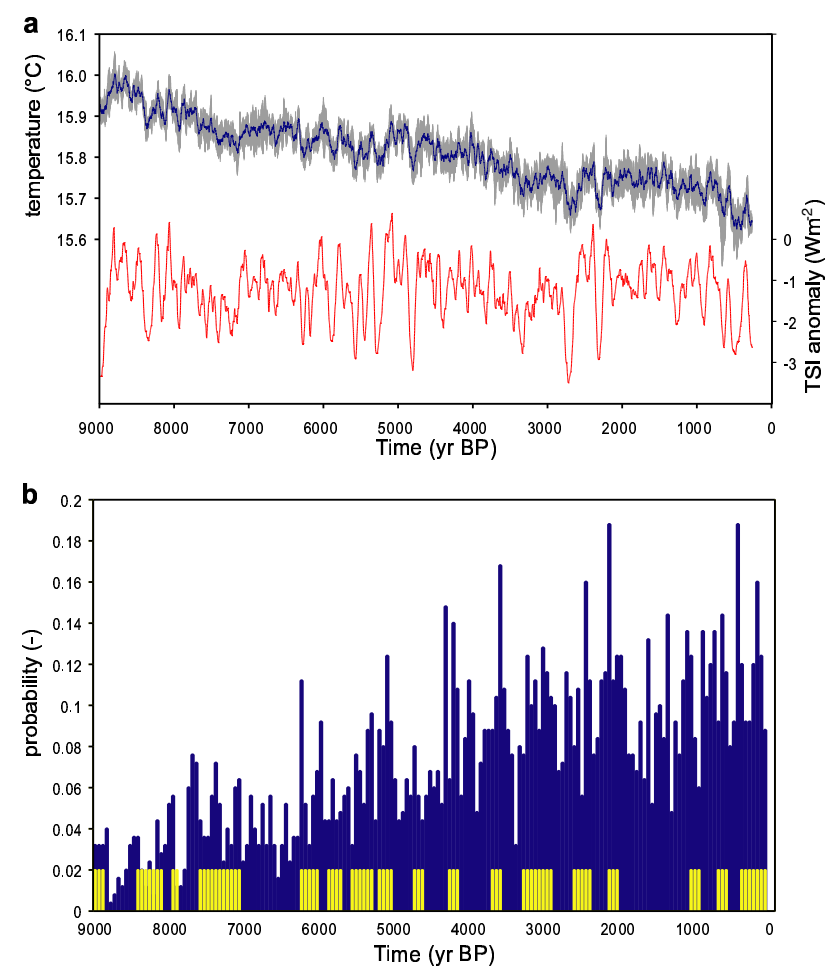

Fig. 2. (a) Simulated 5-member ensemble mean annual global surface temperature (25-year running means, left axis) and the ensemble range (in grey) plotted together with TSI anomalies (in red, right axis). (b) Probability to have an extremely cold year over Nordic Seas just South of Svalbard (main deep convection area), calculated per 50-year periods. The probability is defined as the occurrences of years with an annual temperature of more than 2 standard deviations below the 9000-year mean per 50-year periods in the 5 ensemble members, divided by the total number of years (i.e. 250 years). The long-term cooling trend due to orbital forcing is removed before the analysis by subtracting a linear regression model that was fitted through the annual data. The yellow bars indicate large TSI anomalies (reaching values lower than $-2 \mathrm{Wm}^{-2}$ ), with the start and end points defined as the moment when the overall mean (i.e. calculated over 9000 years) TSI anomaly value $\left(-1.27 \mathrm{Wm}^{-2}\right)$ is crossed.

(Renssen et al., 2005b). During these seasons, the positive insolation difference between the early Holocene (i.e. 9 ka BP) and today was at its maximum at high latitudes $\left(+60 \mathrm{Wm}^{-2}\right.$ at $60^{\circ} \mathrm{N}$ in June, and $+37 \mathrm{Wm}^{-2}$ at $60^{\circ} \mathrm{S}$ in October). At high latitudes, the warming effect of this forcing is amplified by several strong positive feedbacks, i.e. the ice-albedo feedback, the sea ice-insulation feedback, and the tundra-taiga feedback (only relevant over Arctic continents). Moreover, part of the excess heat is stored in the oceans due to their large heat capacity. As a result, at $9 \mathrm{ka}$ BP the high-latitude oceans are warmer than today throughout the year (Renssen et al., 2005a, b). According to our model, the annual mean temperature at $9 \mathrm{ka}$ was 1 to $5^{\circ} \mathrm{C}$ above the present level in the Arctic (Renssen et al., 2005a) and 0.5 to $1.5^{\circ} \mathrm{C}$ at Southern high latitudes (Renssen et al., 2005b). 
Table 1. Overview of the relation between major TSI anomalies $\left(<-2 \mathrm{Wm}^{-2}\right.$, yellow bars in Fig. 2b) and the probability to have an extremely cold year in the Nordic Seas, which has been computed per 50 -year periods in 5 ensemble members (i.e. 250 yr in total). For comparison, the probability in the reference experiment (Renssen et al., 2005a) without TSI variability is included. The latter probability is calculated for the four 250-yr periods per millennium (9-8 ka, 8-7 ka etc.) and one standard deviation is added to account for variability within a millennium. The bold numbers show the cases where the reference level is reached in the ensemble experiment with solar forcing.

\begin{tabular}{|c|c|c|c|c|c|c|}
\hline \multirow{2}{*}{$\begin{array}{c}\text { TSI anomaly } \\
\#\end{array}$} & \multirow{2}{*}{$\begin{array}{c}\text { Maximum TSI } \\
\text { Anomaly }\left(\mathrm{Wm}^{-2}\right)\end{array}$} & \multicolumn{2}{|c|}{ Timing in $50-y r$ periods } & \multirow{2}{*}{$\begin{array}{l}\text { Duration in } 50-\mathrm{yr} \\
\text { periods (yr) }\end{array}$} & \multirow{2}{*}{$\begin{array}{l}\text { Maximum probability in Solar } \\
\text { forced runs (per } 50 \mathrm{yr} \text { ) }\end{array}$} & \multirow{2}{*}{$\begin{array}{l}\text { Probability in reference } \\
\text { experiment (mean }+1 \mathrm{sd})\end{array}$} \\
\hline & & Begin (yr BP) & End (yr BP) & & & \\
\hline 1 & -3.3 & 9000 & 8850 & 150 & 0.032 & 0.051 \\
\hline 2 & -2.5 & 8450 & 8100 & 350 & 0.044 & 0.051 \\
\hline 3 & -2.2 & 8000 & 7900 & 100 & 0.056 & 0.046 \\
\hline 4 & -2.5 & 7650 & 7100 & 550 & 0.072 & 0.046 \\
\hline 5 & -2.6 & 6350 & 6100 & 250 & 0.112 & 0.068 \\
\hline 6 & -2.5 & 6000 & 5800 & 200 & 0.064 & 0.045 \\
\hline 7 & -2.9 & 5700 & 5400 & 300 & 0.096 & 0.045 \\
\hline 8 & -2.8 & 5350 & 5100 & 150 & 0.124 & 0.045 \\
\hline 9 & -3.2 & 4900 & 4750 & 150 & 0.080 & 0.108 \\
\hline 10 & -2.2 & 4450 & 4300 & 150 & 0.140 & 0.108 \\
\hline 11 & -2.1 & 3900 & 3750 & 150 & 0.168 & 0.125 \\
\hline 12 & -2.8 & 3500 & 3100 & 400 & 0.128 & 0.125 \\
\hline 13 & -3.5 & 2850 & 2600 & 250 & 0.160 & 0.193 \\
\hline 14 & -2.9 & 2400 & 2250 & 150 & 0.188 & 0.193 \\
\hline 15 & -2.1 & 1350 & 1200 & 150 & 0.124 & 0.205 \\
\hline 16 & -2.1 & 1000 & 850 & 150 & 0.144 & 0.144 \\
\hline 17 & -2.8 & 700 & 350 & 350 & 0.160 & 0.144 \\
\hline
\end{tabular}

Decadal-to-centennial scale variations in the global annual temperature evolution cannot be explained with orbital forcing and appear to be primarily controlled by TSI anomalies at this time-scale ( $r$ is 0.76 after removal of the large-scale cooling trend). For individual ensemble members this relationship is less straightforward ( $r$ is 0.31 ) due to the system's internal variability.

Previous sensitivity experiments (Goosse et al., 2002; Goosse and Renssen, 2004) performed with ECBILT-CLIO focused at TSI anomalies revealed that reductions in radiative forcing could potentially trigger a local temporary shutdown of deep convection in the Nordic Seas (i.e. South of Svalbard). In our model, such local convection failures could take place as part of a low-frequency mode of internal variability (i.e. they also occur without external forcing, Goosse et al., 2002), a phenomenon described in at least one other coupled climate model (Hall and Stouffer, 2001). These events are linked to sea-ice expansion during relatively cold phases, which stratifies the water column and prevents deep convection. In experiments with constant preindustrial forcing (Goosse and Renssen, 2004), the probability for having an extremely cold year over the Nordic Seas that is associated with such a local convection failure is 0.04 .

In our ensemble experiment with variable solar forcing this probability is 0.08 when calculated for the entire 9000 year-period after removal of the orbitally-forced long-term cooling trend by subtracting a linear regression model that was fitted through the annual data. The cooling trend has to be removed because we calculate the probability using the temperature over the main convection site, with extremely low temperatures being indicative for local convection failures (see Fig. 2b, c.f. Goose and Renssen, 2004). The higher probability of 0.08 compared to value of 0.04 reported by Goosse et al. (2002) is probably related to the difference in model versions (i.e. Goosse et al. (2002) used version 2 without VECODE), combined with the difference in experimental setup (i.e. Goosse et al. (2002) prescribed constant preindustrial forcings). Since we focused our attention here on decadal-centennial scale variability, it is more interesting to calculate the probability to have a local convection failure for 50-year periods, which varies between 0 and 0.19 (Fig. 2b). Most of the higher values $(>0.14)$ are associated with TSI minima (7 out of 8 ). Particularly during the last 4500 years, all major negative TSI anomalies (less than $-2 \mathrm{Wm}^{-2}$ or $>2$ standard deviations) are followed by high probability values within 100 years, i.e. centered at 4.3, 3.8, 3.2, 2.6, 2.3, 1.3, $0.9,0.7$ and $0.4 \mathrm{ka} \mathrm{BP}$.

To quantitatively analyse the impact of TSI anomalies on the probability to have a local convection failure in the Nordic Seas, our results should be compared with experiments without varying solar forcing that can provide a reference level. We therefore compare in Table 1 the probability values during the 17 TSI anomalies of less than $-2 \mathrm{Wm}^{-2}$, with average probability values computed for the experiment of Renssen et al. (2005a, b), who used the same model to simulate the long-term response to orbital and greenhouse gas forcing (i.e. equivalent experimental setup, but without TSI variability). In 11 out of 17 cases, the probability during 
the major TSI anomalies is above the reference level (average plus one standard deviation) of the experiment without variable solar forcing. It should be noted that in the experiment without solar forcing the probability is relatively high between 3 and $1 \mathrm{ka}$ BP (i.e. around 0.2), which is connected to two centennial-scale convection failure events that occur spontaneously and are not related to solar forcing (see Fig. 14, Renssen et al., 2005a). This period of the run is thus not a good estimate of the reference level without TSI variations, explaining why the probability during the TSI anomalies centered at 2.7 and $2.3 \mathrm{kaBP}$ does not reach this estimated reference level, although the maximum probability values are well above (0.16 to 0.19$)$ the overall average value of 0.08 and the computed reference value between 1 and $0 \mathrm{kaBP}(0.14)$. We thus argue that Table 1 and Fig. $2 \mathrm{~b}$ suggest that the probability of a convection failure in the Nordic Seas is notably higher after large TSI anomalies than without a reduction in radiative forcing (cf. Goosse and Renssen, 2004).

In the first 4500 years of our experiments, this probability is generally lower than in the second half of the simulations (Table 1, Fig. 2b). The early Holocene climate in the Arctic is relatively warm as a consequence of the high orbitallyforced summer insolation values, leading to reduced sea-ice cover and less interference with deep convection. In the reference simulation (Renssen et al., 2005a) that was forced with orbital forcing and greenhouse gas forcing, the $9 \mathrm{ka}$ BP temperature averaged over the area north of $60^{\circ} \mathrm{N}$ was about $2^{\circ} \mathrm{C}$ above the preindustrial level in both winter and summer, followed by gradual cooling associated with the decreasing summer insolation trend during the Holocene. Similarly, from 9 to $0 \mathrm{ka} \mathrm{BP}$ the simulated summer sea-ice area in the Arctic increased by $3.5 \times 10^{6} \mathrm{~km}^{2}$ (Renssen et al., 2005a).

\subsection{The simulated climate response during 3000- 2000 yr BP}

The impact of solar forcing on deep convection and the surface climate can be illustrated in detail using the 3000$2000 \mathrm{yr}$ BP period, which includes two marked negative TSI anomalies centred at $2700 \mathrm{yr} \mathrm{BP}$ and $2300 \mathrm{yr} \mathrm{BP}$ (Fig. 3a). For this period we performed four additional 1500-year long experiments that differ in initial conditions (started at $3500 \mathrm{yr}$ BP). In general, the global atmospheric surface temperature closely follows the TSI anomaly. During the period with lowest TSI values (2730-2700 yr BP), generally cooling occurs around the globe, with strongest cooling (up to $0.5^{\circ} \mathrm{C}$ in the ensemble mean) over Northern Hemisphere (NH) midlatitude continents (Fig. 4a), while the temperature reduction over the oceans is relatively small (generally $<0.1^{\circ} \mathrm{C}$ ) due to the ocean's large heat capacity. An exception is the Arctic Ocean, where the insulating sea-ice cover results in a more direct influence of the TSI reduction on the surface temperature. In the Nordic Seas region a characteristic temperature anomaly pattern is visible with enhanced cooling (more than

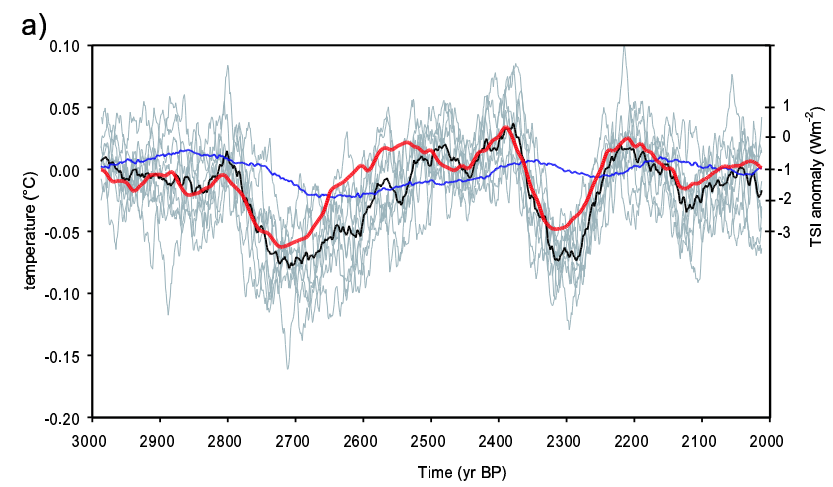

b)

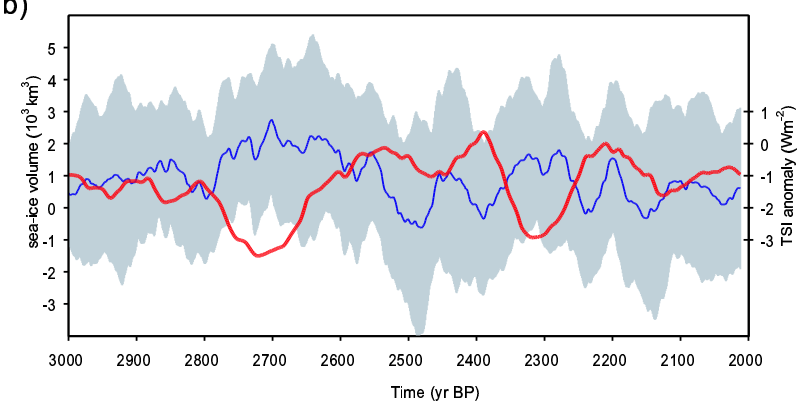

Fig. 3. Simulated 9-member ensemble mean time-series (left axis) together with TSI anomalies (red curves, right axis) for the period 3000-2000 yr BP: (a) global annual atmospheric surface temperature anomaly (25-year running mean, ensemble mean in black, reference period is $3000-2900 \mathrm{yr} \mathrm{BP}$ ) with the individual ensemble members shown (in grey) and global ocean temperature (blue), (b) annual sea-ice volume in the Northern Hemisphere (25-year running mean, ensemble mean in dark blue) and \pm 1 standard deviation in grey. The long-term trend is removed (see caption Fig. 2b).

$\left.-0.6^{\circ} \mathrm{C}\right)$ South of Svalbard and warming $\left(0.4^{\circ} \mathrm{C}\right)$ near Iceland, associated with a shift in deep water formation from the former to the latter location. After the lowest TSI values at $2700 \mathrm{yr}$ BP, the global surface temperature and TSI diverge. Between 2650 and $2600 \mathrm{yr}$ BP, when the TSI values have increased again, temperatures remain relatively low (Fig. 3a). This can be explained by the considerable build-up of Arctic sea-ice (Fig. 3b) between 2700 and 2650 yr BP, which sustains the local deep convection shutdown South of Svalbard, causing an amplified cooling over the eastern Nordic Seas and Barents Sea (Fig. 4b).

In 2 (out of 9) ensemble members, this shift in convection location is accompanied by important reductions in the strength of the meridional overturning circulation (MOC) in the Nordic Seas (from 3.1 Sv to $2.5 \mathrm{~Sv}$, or $19 \%$ reduction). The blue curve in Fig. 5 depicts an example of such a reduction, showing a sharp decline just after $2650 \mathrm{yr} \mathrm{BP}$, after which the MOC strength in the Nordic Seas remains at a relatively low level for another century before increasing again to the level before $2650 \mathrm{yr}$ BP. The ensemble mean result (signifying the forced response) is also shown for reference. In the decade with the strongest reduction MOC in the ensemble 

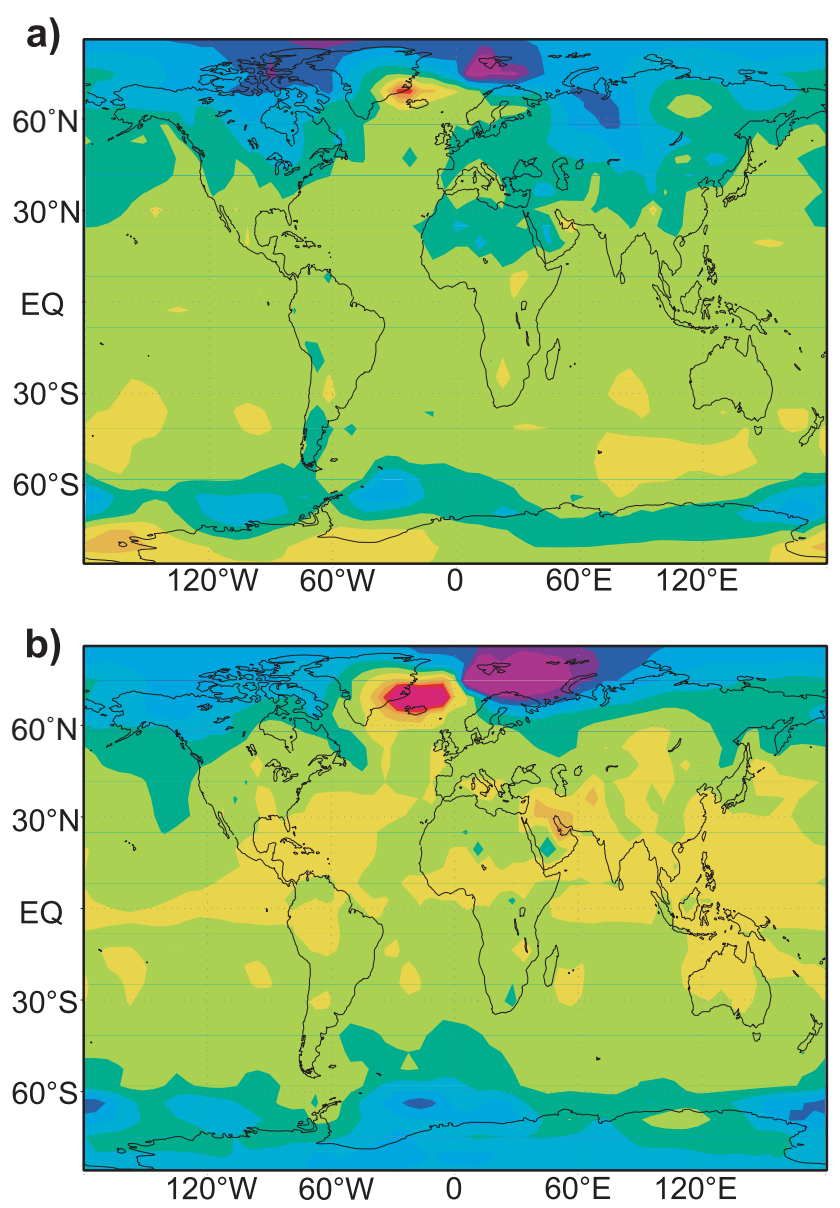

$\begin{array}{lllllllllll}-0.6 & -0.5 & -0.4 & -0.3 & -0.2 & -0.1 & 0 & 0.1 & 0.2 & 0.3 & 0.4{ }^{\circ} \mathrm{C}\end{array}$

Fig. 4. Simulated annual surface temperature anomaly compared to ensemble mean for 3000-2950 yr BP (in ${ }^{\circ} \mathrm{C}$ ): (a) 9-member ensemble mean 2730-2700 yr BP (maximum TSI reduction), (b) 9member ensemble mean 2650-2600 yr BP (period when global temperature and TSI diverge).

member (in this example 2648-2639 yr BP), typically there is a cessation of deep convection south of Svalbard (compare Fig. 6b with Fig. 6a), which is accompanied by an expansion of sea ice (Fig. 6c) and strong surface cooling (by more than $10^{\circ} \mathrm{C}$ ) in this area (Fig. 6d). Consequently, the maximum cooling in individual ensemble members can be substantially larger than the ensemble mean (i.e. more than $1^{\circ} \mathrm{C}$ in Northern Europe, Fig. 6d). The MOC reduction of the events discussed here $(-0.6 \mathrm{~Sv})$ is much smaller in magnitude than the $-10 \mathrm{~Sv}$ anomaly reported by Goosse et al. (2002). However, this is related to the earlier model version used by Goosse et al. (2002), which simulated an unrealistically strong MOC and intense recirculation of deep waters in the Nordic Seas (18 Sv).

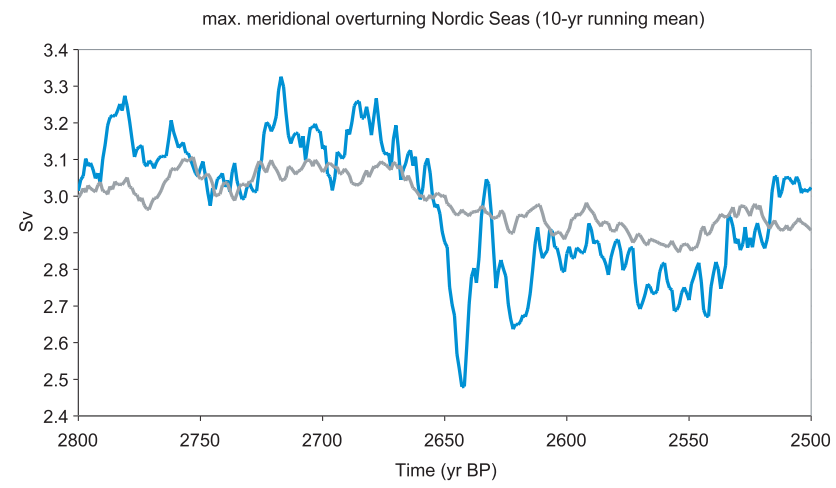

Fig. 5. Simulated annual-mean maximum overturning streamfunction in the Nordic Seas for the period 2800-2500 yr BP for one particular ensemble member (blue line) and the 9-member ensemble mean (gray line). Shown is the 10 -year running mean.

The global atmospheric temperature response to the second negative TSI anomaly centred at $2300 \mathrm{yr} \mathrm{BP}$ is more direct and shows no lag as observed after $2700 \mathrm{yr}$ BP (Fig. 3a). This is probably related to the shorter duration of this TSI anomaly and to the relatively high TSI values before and after the negative excursion. In all ensemble members a temporary local convection-shutdown is simulated around $2300 \mathrm{yr}$ BP similar to $2700 \mathrm{yr} \mathrm{BP}$, but the TSI anomaly centred at $2300 \mathrm{yr}$ BP is too short for extensive sea-ice build-up that extends the cooling (Fig. 3b). Indeed, in our ensemble experiment, significant extension of the cooling event is only seen after a few relatively long-lasting TSI anomalies (i.e. at 5.2, 2.7 and $0.5 \mathrm{ka} \mathrm{BP}$ ).

Associated with major negative TSI anomalies, also a characteristic pattern in precipitation is simulated, with a marked drying over the Northern Africa, where precipitation is reduced by more than $10 \%$ (or $20-40 \mathrm{~mm}$ ) on an annual basis (not shown). This can be partly explained by weakened summer monsoons, related to a stronger continental cooling compared to the tropical oceans. In addition, vegetation cover decreases locally by up to $10 \%$, thus increasing the surface albedo, resulting in amplification of the surface cooling and precipitation decrease. The model simulates no important vegetation changes in other areas, explaining why precipitation anomalies elsewhere in the monsoonal domain are relatively small and statistically insignificant.

\subsection{Comparison with proxy evidence for the 2800- 2600 yr BP event}

When comparing proxy data with our model results, it is important to realise that reality represents only one out of many possible realizations of the climate system. The climate signal registered in proxy data is the combined effect of internal variability and external forcings such as TSI variations. Consequently, when comparing model results for the 2800 $2600 \mathrm{yr}$ BP event with proxy data, we should not look at 

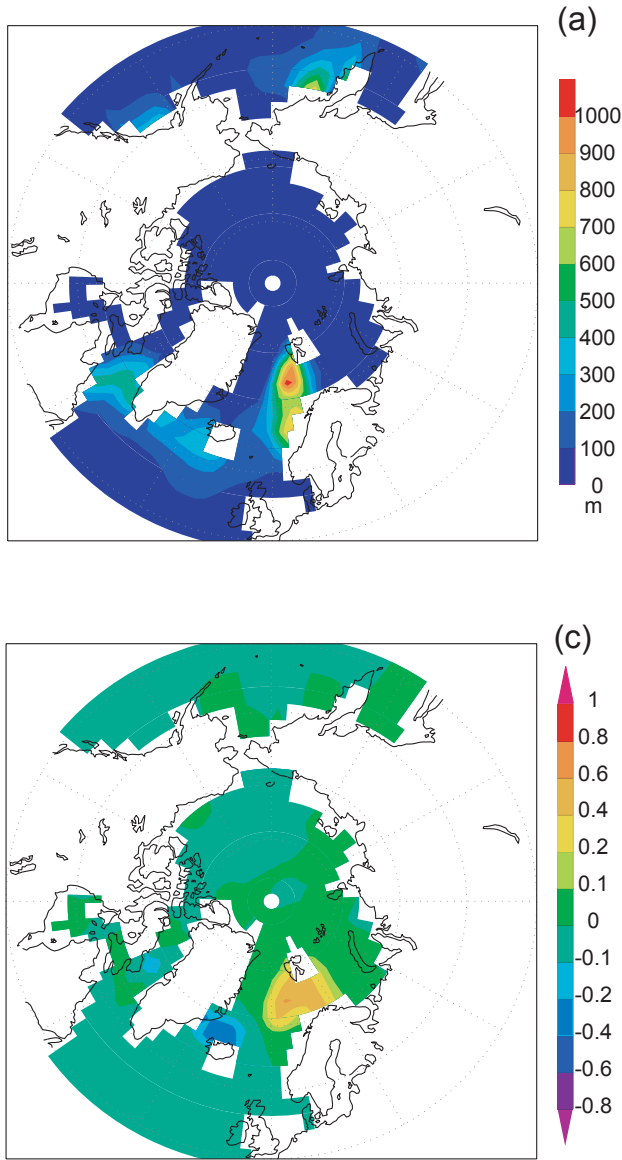

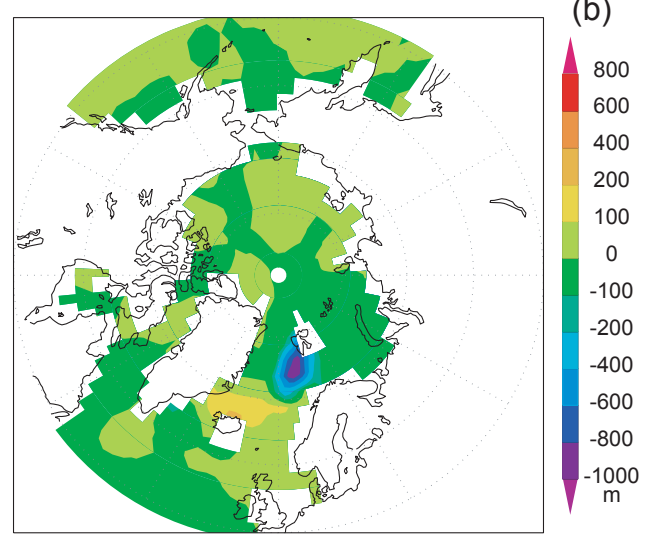

(d)

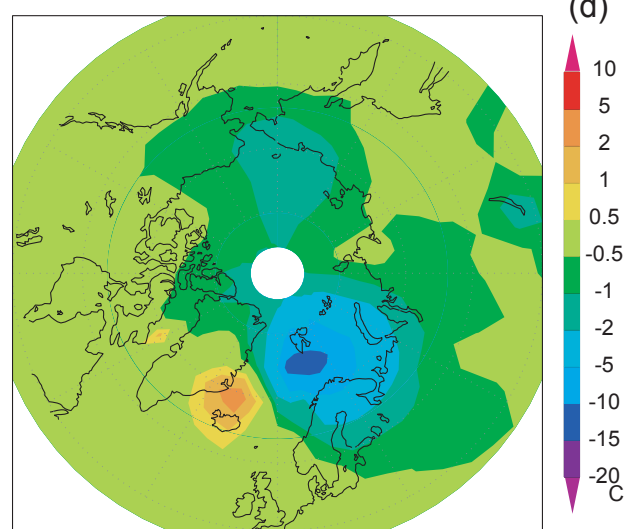

Fig. 6. Simulated fields for March derived from the ensemble member shown in Fig. 5. (a) Convection depth (in metres) averaged over the period 3000-2500 yr BP. (b) Change in convection depth (in metres) during the decade with strongest reduction in overturning in Fig. 5, 2648-2639 yr BP minus 3000-2500 yr BP, (c) Change in sea-ice cover (fraction, e.g., -0.4 means $-40 \%$ ) during the decade with strongest reduction in overturning in Fig. 5, 2648-2639 yr BP minus 3000-2500 yr BP, (d) Surface temperature anomaly $\left({ }^{\circ} \mathrm{C}\right)$ for the decade with strongest reduction in overturning in Fig. 5, 2648-2639 yr BP minus 3000-2500 yr BP. The negative anomaly of less than $-0.5^{\circ} \mathrm{C}$ over Northern Europe is statistically significant at the $95 \%$ level according to a student-t test.

the ensemble mean that represents only the forced response. Rather, if model and data are consistent, one would expect that the proxy signal lies within the simulated climate range of the ensemble set that includes the forced response and internal variability (c.f., Goosse et al., 2005b; 2006). In this respect, the climatic signal registered in proxies is analogous to results of a particular ensemble member. In our experiments, the ensemble members that are closest to these paleodata are the ensemble members with an important reduction in the MOC in the Nordic Seas (Figs. 5 and 6b-d).

Most simulated climate anomalies for the 2800$2600 \mathrm{yr}$ BP event are consistent with proxy evidence (Table 2). North Atlantic marine records show a marked surface cooling, particularly in the Norwegian Sea (Mikalsen et al., 2001; Andersson et al., 2003; Risebrobakken et al., 2003) where the anomaly reached $-1.5^{\circ} \mathrm{C}$, which is in the range of our best-fitting ensemble member (Fig. 6d). Moreover, the cold surface waters in the Nordic Sea (Fig. 6d) could favour the southward advection of drift ice transporting IRD (Bond et al., 2001). Deep ocean records strongly suggest that the surface cooling is accompanied by a distinct reduction in MOC strength (Bianchi and McCave, 1999; Oppo et al., 2003; Hall et al., 2004). In Europe the 2800-2600 yr BP period was a widespread cool phase, with dry conditions in Norway (Nesje et al., 2001), but relatively wet conditions in Western Europe (e.g., Magny, 1993; van Geel et al., 1996, 1998; Macklin et al., 2003; Holzhauser et al., 2004). In Eastern North America (New England and Michigan) also proxy evidence is found for anomalous wet conditions aound 28002600 yr BP (Brown et al., 2000; Booth and Jackson, 2003). The increases in precipitation at NH mid-latitudes in our simulation results are very small and not statistically significant.

The simulated warming near Iceland (see Fig. 6d) agrees with some records indicating that the North Icelandic shelf experienced a warm inflow (e.g., Giraudeau et al., 2004; Andersen et al., 2004) starting at $2800 \mathrm{yr}$ BP. Other marine 
Table 2. Summary of proxy evidence for climate change in period 2800-2600 yr BP

\begin{tabular}{|c|c|c|}
\hline Region & Inferred climate change $2800-2600 \mathrm{yr}$ BP & References \\
\hline Greenland ice cores (regional signal) & Cold phase, intensified atmospheric circulation & O’Brien et al. (1995) \\
\hline N Icelandic Shelf & $\begin{array}{l}\text { Relatively warm phase/cold phase followed } \\
\text { by warming }\end{array}$ & $\begin{array}{l}\text { Andersen et al. (2004), Giraudeau et } \\
\text { al. (2004)/Jiang et al. (2002) }\end{array}$ \\
\hline N Europe (Norway) & Cold/dry phase & Nesje et al. (2001) \\
\hline $\begin{array}{l}\text { W Europe (UK, Ireland, } \\
\text { France, Netherlands) }\end{array}$ & Widespread cold/wet phase & $\begin{array}{l}\text { Magny (1993), van Geel et al. (1996, } \\
\text { 1998), Macklin et al. (2003), } \\
\text { Holzhauser et al. (2005) }\end{array}$ \\
\hline North Atlantic surface ocean & Changes in surface winds and colder surface ocean & Bond et al. (2001) \\
\hline North Atlantic deep ocean & Reduced MOC & $\begin{array}{l}\text { Bianchi and McCave (1999), Oppo et } \\
\text { al. (2003), Hall et al. (2004) }\end{array}$ \\
\hline NW Africa & Distinct dry event & $\begin{array}{l}\text { Van Geel et al. (1998), Elenga et } \\
\text { al. (2004) }\end{array}$ \\
\hline
\end{tabular}

records from this region indicate first a cold phase, followed by a warming (Jiang et al., 2002). Because of the local warming near Iceland, there is no clear cooling signal over Greenland in our model, which is consistent with the reconstructed stable site (i.e. local) temperature for the Greenland ice cores (Masson-Delmotte et al., 2005). However, analysis of variations in chemical species in the GISP2 ice core that reflect changes in atmospheric circulation (i.e. a regional signal) have revealed anomalous cold and windy conditions in the period 2800-2600 yr BP (O'Brien et al., 1995). It is unclear if the simulated reduction in precipitation over Northwestern Africa has a counterpart in proxy data. A marked dry event has been dated to 2800-2600 yr BP in various types of records along the coast (van Geel et al., 1998; Elenga et al., 2004), but more inland the timing of dry spells between 4000 and $2000 \mathrm{yr}$ BP varies from place to place (Hoelzmann et al., 2004).

In summary, proxy data show that the 2800-2600 yr BP is characterised by widespread cooling (especially in the North Atlantic region), reduced MOC strength, wet conditions over NH mid-latitude continents. Proxy archives show a very similar climate anomaly around $5300 \mathrm{yr}$ BP (Magny and Haas, 2004), i.e. the timing of a major TSI minimum and extended cool phase in our simulations. Our results show many similarities to this characteristic pattern, suggesting that centennial-scale Holocene cooling events could be an expression of the combined effect of solar forcing and the discussed positive oceanic feedback, indicating a larger role for the oceans in driving centennial-scale climate changes than recognized until now. Our simulation results suggest that the probability of a local deep convection failure in the Nordic Seas increases in periods following a major negative TSI anomaly. Consequently, in the real world not all TSI reductions should necessarily have resulted in such a local convection shut-down and conversely, these convection failures could also have occurred without relatively low TSI values in the preceding period. The stochastic nature of the discussed oceanic feedback could thus explain why the correlation between reconstructed TSI and climate reconstructions is generally lower on decadal-centennial timescales than might be expected in the case of a direct linear solar-climate link.

\subsection{Comparison with other model studies}

Our simulation results may seem contradictory to Weber et al. (2004), who found an anticorrelation between TSI and MOC strength in a 10000-year simulation using the ECBilt model, forced by variations in orbital parameters and TSI. However, it should be noted that we used a more comprehensive model. Our model only has the atmospheric component ECBilt in common with the model version utilized by Weber et al. (2004), as they used a version with a flat-bottom 
ocean model without sea-ice dynamics at lower resolution (T21) and no dynamic vegetation component. An important difference is that in our model, the deep convection in the Nordic Seas is controlled by the sea-ice cover. As discussed in detail before (Goosse et al., 2003; Goosse and Renssen, 2004; Renssen et al., 2005c), sea-ice expansion in the Nordic Seas associated with cooling leads to reduced deep convection in the Nordic Seas, whereas the opposite occurs in case of warming. This is fully consistent with the events described in the present paper. On the other hand, it is important to separate this regional effect in the Nordic Seas from the impact of warming/cooling on the overall overturning strength in the North Atlantic, as this is also affected by the response of deep convection in the Labrador Sea (i.e. the other major site of deep convection in our model) that could compensate for the response in the Nordic Seas. As for instance discussed by Renssen et al. (2005c), the deep convection in the Labrador Sea is much less influenced by sea ice and may show an opposite response to cooling/warming compared to the Nordic Seas.

Previous studies have suggested that the amplifying factor behind Holocene cooling events involves a stratospheric response to TSI reductions (Haigh, 1994, 1996; van Geel et al., 1998, 2000; van Geel and Renssen, 1998). This was based on model studies (Haigh, 1994, 1996) indicating that during negative TSI anomalies the relatively large reduction in incoming UV radiation caused decreases in lower stratospheric ozone formation, resulting in amplified stratospheric cooling and a change in circulation that could propagate downward. In the troposphere, this could lead to contraction of the Hadley Cells and expansion of the polar cells, resulting in drier conditions in the tropics and cooling at mid-latitudes (Haigh, 1994; van Geel et al., 1998). Other model studies have also addressed these dynamical effects of stratospheric ozone changes relating to TSI variations (Shindell et al., 1999, 2001; Palmer et al., 2004). Our model does not include this mechanism as it lacks a dynamical stratosphere. Consequently, in our simulations the cool mid-latitudes cannot be attributed to this stratospheric mechanism. However, as mentioned, TSI reconstructions extending the period of direct satellite-based observation contain an uncertainty so that it is unclear by how much TSI was reduced during periods such as the Maunder minimum. Our estimate is probably at the upper limit of realistic estimates (e.g., Wang et al., 2005) of the changes from periods with almost no sunspots to periods of relatively high solar activity. Changes in ozone and energy absorption in the stratosphere due to the variable sun, however, could amplify the direct solar forcing and act in a similar way, also resulting in a displacement the location of deep convection. Therefore, in future climate modelling studies considering the impact of TSI variations on the Holocene climate, the effect of stratospheric ozone should ideally be accounted for.

\section{Conclusions}

We have presented transient experiments performed with a coupled climate model to investigate the impact of TSI variations on decadal-centennial scale climate variability during the last 9000 years. Our results suggest the following.

1. In our model, negative TSI anomalies increase the probability of a local shutdown of deep convection in the Nordic Seas. The initial cooling associated with TSI reductions leads to sea-ice expansion in the area, which stratifies the water column and hampers deepwater formation, leading to additional cooling and more seaice. This positive oceanic feedback amplifies the solarforced cooling in the North Atlantic region.

2. In the first 4500 years of our simulation, the probability to have a local convection failure in the Nordic Seas is smaller than during the second half of our simulations. This is probably related to the relatively warm early Holocene climate at high northern latitudes, which is due to the relatively high orbitally-forced summer insolation at that time.

3. Following relatively long-lasting negative TSI anomalies (centered at 5.2, 2.7 and $0.5 \mathrm{ka} \mathrm{BP}$ ), extensive seaice buildup results in extension of the cooling event by about 50 years. This extension is not occuring after relatively short TSI anomalies.

4. The characteristic climatic anomalies for simulated events centered around 5.2 and $2.7 \mathrm{kaBP}$ are consistent with proxy evidence, suggesting that the positive oceanic feedback has played an important role in driving Holocene cooling events.

Acknowledgements. The comments of M. Crucifix and two anonymous referees are gratefully acknowledged. H.R. is supported by the Netherlands Organization for Scientific Research (N.W.O). H.G. is Research Associate with the Fonds National de la Recherche Scientifique (Belgium) and is supported by the Belgian Federal Science Policy Office. RM was supported by the Swiss National Science Foundation and NASA.

Edited by: V. Masson-Delmotte

\section{References}

Andersen, C., Koç, N., Jennings, J., and Andrews, J. T.: Nonuniform response of the major surface currents in the Nordic Seas to insolation forcing: implications for the Holocene climate variability, Paleoceanogr., 19, PA2003, doi:10.1029/2002PA000873, 2004.

Andersson, C., Risebrobakken, B., Jansen, E., and Dahl, S. O.: Late Holocene surface ocean conditions of the Norwegian Sea (Vøring Plateau), Paleoceanogr., 18, 1044, doi:10.1029/2001PA000654, 2003. 
Berger, A. L.: Long-term variations of daily insolation and Quaternary climatic changes, J. Atmos. Sci. 35, 2363-2367, 1978.

Bertrand, C., van Ypersele, J.-P., and Berger, A.: Volcanic and solar impacts on climate since 1700, Clim. Dyn., 15, 355-367, 1999.

Bianchi, G. G. and McCave, I. N.: Holocene periodicity in North Atlantic climate and deep-ocean flow south of Iceland, Nature, 397, 515-517, 1999.

Bond, G., Showers, W., Cheseby, M., Lotti, R., Almasi, P., deMenocal, P., Priore, P., Cullen, H., Hajdas, I., and Bonani, G.: A pervasive millennial-scale cycle in North Atlantic Holocene and Glacial climates, Science, 278, 1257-1266, 1997.

Bond, G. C., Showers, W., Elliot, M., Evans, M., Lotti, R., Hajdas, I., Bonani, G., and Johnsen, S.: The North Atlantic's 1-2 kyr climate rhythm: relation to Heinrich events, Dansgaard/Oeschger cycles and the Little Ice Age, AGU Geophys. Monogr., 112, 3558, 1999.

Bond, G. C., Kromer, B., Beer, J., Muscheler, R., Evans, M. N., Showers, W., Hoffmann, S., Lotti-Bond, R., Hajdas, I., and Bonani, G.: Persistent solar influence on North Atlantic climate during the Holocene, Science, 294, 2130-2133, 2001.

Booth, R. K. and Jackson, S. T.: A high-resolution record of late-Holocene moisture availability from a Michigan raised bog, USA, Holocene, 13, 863-876, 2003.

Brovkin, V., Bendtsen, J., Claussen, M., Ganopolski, A., Kubatzki, C., Petoukhov, V., and Andreev, A.: Carbon cycle, vegetation and climate dynamics in the Holocene: experiments with the CLIMBER-2 model, Global Biogeochem. Cycles, 16, 1139, doi:10.1029/2001GB001662, 2002.

Brown, S. L., Bierman, P. R., Lini, A., and Southon, J.: 10000 yr record of extreme hydrological events, Geology, 28, 335-338, 2000.

Cubasch, U., Voss, R., Hegerl, G. C., Waszkewitz, J., and Crowley, T. J.: Simulation of the influence of solar radiation variations on the global climate with an ocean-atmosphere general circulation model, Clim. Dyn., 13, 757-767, 1997.

Denton, G. H. and Karlén, W.: Holocene climatic variations - Their pattern and possible causes, Quat. Res., 3, 155-205, 1973.

Eddy, J. A.: The Maunder minimum, Science, 192, 1189-1202, 1976.

Elenga, H., Maley, J., Vincens, A., and Farrera, I.: Palaeoenvironments, palaeoclimates and landscape development in Atlantic Equatorial Africa: a review of key sites covering the last $25 \mathrm{kyrs}$, in: Past climate variability through Europe and Afrcia, edited by: Battarbee, R. W., Gasse, F., and Stickley, C. E., Springer, Dordrecht, 181-198, 2004.

Fröhlich, C. and Lean, J.: Solar radiative output and its variability: evidence and mechanisms, Astron. Astroph. Rev., 12, 273-320, 2004.

Giraudeau, J., Jennings, A. E., and Andrews, J. T.: Timing and mechanisms of surface and intermediate water circulation changes in the Nordic Seas over the last 10000 cal years: a view from the North Iceland shelf, Quat. Sci. Rev., 23, 2127-2139, 2004.

Goosse, H. and Fichefet, T.: Importance of ice-ocean interactions for the global ocean circulation: a model study, J. Geophys. Res., 104, 23 337-23 355, 1999.

Goosse, H. and Renssen, H.: Exciting natural modes of variability by solar and volcanic forcing: idealized and realistic experiments, Clim. Dyn., 23, 153-163, 2004.
Goosse, H., Selten, F. M., Haarsma, R. J., and Opsteegh, J. D.: Decadal variability in high northern latitudes as simulated by an intermediate-complexity climate model, Ann. Glaciol., 33, 525532, 2001.

Goosse, H., Renssen, H., Selten, F. M., Haarsma, R. J., and Opsteegh, J. D.: Potential causes of abrupt climate events: a numerical study with a three-dimensional climate model, Geophys. Res. Lett., 29, 1860, doi:10.1029/2002GL014993, 2002.

Goosse, H., Selten, F. M., Haarsma, R. J., and Opsteegh, J. D.: Large sea-ice volume anomalies simulated in a coupled climate model, Clim. Dyn., 20, 523-536, 2003.

Goosse, H., Masson-Delmotte, V., Renssen, H., Delmotte, M., Fichefet, T., Morgan, V., van Ommen, T., Khim, B. K., and Stenni, B.: A late medieval warm period in the Southern Ocean as a delayed response to external forcing?, Geophys. Res. Lett., 31, L06203, doi:10.1029/019140, 2004.

Goosse, H., Crowley, T. J., Zorita, E., Ammann, C. M., Renssen, H., and Driesschaert, E.: Modelling the climate of the last millennium: what causes the differences between simulations?, Geophys. Res. Lett., 32, L06710, doi:10.1029/2005GL022368, 2005a.

Goosse, H., Renssen, H., Timmermann, A., and Bradley, R. S.: Internal and forced climate variability during the last millennium: A model-data comparison using ensemble simulations, Quat. Sci. Rev., 24, 1345-1360, 2005b.

Goosse, H., Renssen, H., Timmermann, A., Bradley, R. S., and Mann, M. E.: Using paleoclimate proxy-data to select optimal realisations in an ensemble of simulations of the past millennium, Clim. Dyn., 27, 165-184, 2006.

Gregory, J. M., Dixon, K. W., Stouffer, R. J., et al.: A model intercomparison of changes in the Atlantic thermohaline circulation in response to increasing atmospheric $\mathrm{CO} 2$ concentration, Geophys. Res. Lett., 32, L12703, doi:10.1029/2005GL023209, 2005.

Haigh, J. D.: The role of stratospheric ozone in modulating the solar radiative forcing of climate, Nature, 370, 544-546, 1994.

Haigh, J. D.: The impact of solar variability on climate, Science, 272, 981-984, 1996.

Hall, A. and Stouffer, R. J.: An abrupt climate event in a coupled ocean-atmosphere simulation without external forcing, Nature, 409, 171-174, 2001.

Hall, I. R., Bianchi, G. G., and Evans, J. R.: Centennial to millennial scale Holocene climate-deep water linkage in the North Atlantic, Quat. Sci. Rev., 23, 1529-1536, 2004.

Hoelzmann, P., Gasse, F., Dupont, L. M., Salzmann, U., Staubwasser, M., Leuschner, D. C., and Sirocko, F.: Palaeoenvironmental changes in the arid and subarid belt (Sahara-SahelArabian Peninsula) from $150 \mathrm{kyr}$ to present, in: Past climate variability through Europe and Afrcia, edited by: Battarbee, R. W., Gasse, F., and Stickley, C. E., Springer, Dordrecht, 219-256, 2004.

Holzhauser, H., Magny, M., and Zumbühl, H. J.: Glacier and lakelevel variations on west-central Europe over the last 3500 years, Holocene, 15, 789-801, 2005.

Jiang, H., Seidenkrantz, M. S., Knudsen, K. L., and Eiriksson, J.: Late-Holocene summer sea-surface temperatures based on a diatom record from the north Icelandic shelf, Holocene, 12, 137$147,2002$.

Lean, J.: Evolution of the Sun's Spectral Irradiance Since the Maunder Minimum, Geophys. Res. Lett., 27, 2425-2428, 2000. 
Lean, J. L., Wang, Y. M., and Sheeley, N. R.: The effect of increasing solar activity on the Sun's total and open magnetic flux during multiple cycles: Implications for solar forcing of climate, Geophys. Res. Lett., 29, 2224, doi:10.1029/2002GL0158880, 2002.

Luterbacher, J., Dietrich, D., Xoplaki, E., Grosjean, M., and Wanner, H.: European seasonal and annual temperature variability, trends and extremes since 1500 AD, Science, 303, 1499-1503, 2004.

Macklin, M. G., Johnstone, E., and Lewin, J.: Pervasive and longterm forcing of Holocene river instability and flooding in Great Britain by centennial-sclae climate change, Holocene, 15, 937943, 2003

Magny, M., and Haas, J. N.: A major widespread climatic change around 5300 cal. yr BP at the time of the Alpine Iceman, J. Quat. Sci., 19, 423-430, 2004.

Magny, M.: Solar influences on Holocene climatic changes illustrated by correlations between past lake-level fluctuations and the atmospheric ${ }^{14} \mathrm{C}$ record, Quat. Res., 40, 1-9, 1993.

Masarik, J. and Beer, J.: Simulation of particle fluxes and cosmogenic nuclide production in the Earth's atmosphere, J. Geophys. Res., 104, 12 099-12 111, 1999.

Masson-Delmotte, V., Landais, A., Stievenard, M., Cattani, O., Falourd, S., Jouzel, J., Johnsen, S. J., Dahl-Jensen, D., Sveinsbjorndottir, A., White, J. W. C., Popp, T., and Fischer, H.: Holocene climatic changes in Greenland: different deuterium excess signals at Greenland ice core project (GRIP) and NorthGRIP, J. Geophys. Res., 110, D14102, doi:10.1029/2004JD005575, 2005.

Mikalsen, G., Sejrup, H. P., and Aarseth, I.: Late-Holocene changes in ocean circulation and climate: foraminiferal and isotopic evidence from Sulafjord, western Norway, Holocene, 11, 437-446, 2001.

Muscheler, R., Beer, J., Wagner, G., Laj, C., Kissel, C., Raisbeck, G. M., Yiou, F., and Kubik, P. W.: Changes in the carbon cycle during the last deglaciation as indicated by the comparison of ${ }^{10} \mathrm{Be}$ and ${ }^{14} \mathrm{C}$ records, Earth Planet. Sci. Lett., 219, 325-340, 2004a.

Muscheler, R., Beer, J., and Vonmoos, M.: Causes and timing of the $8200 \mathrm{yr}$ BP event inferred from the comparison of the GRIP ${ }^{10} \mathrm{Be}$ and the tree ring $\Delta^{14} \mathrm{C}$ record, Quat. Sci. Rev., 23, 2105-2115, 2004b.

Muscheler, R., Beer, J., Kubik, P. W., and Synal, H.-A.: Geomagnetic field intensity during the last 60000 years based on ${ }^{10} \mathrm{Be}$ $\&{ }^{36} \mathrm{Cl}$ from the Summit ice cores and ${ }^{14} \mathrm{C}$, Quat. Sci. Rev., 24, 1849-1860, 2005.

Nesje, A., Matthews, J. A., Dahl, S. O., Berrisford, M. S., and Andersson, C.: Holocene glacier fluctuations of Flatebreen and winter-precipitation changes in the Jostedalsbreen, western Norway, based on glaciolacustrine sediment records, Holocene, 11, 267-280, 2001.

O’Brien, S. R., Mayewski, P. A., Meeker, L. D., Meese, D. A., Twickler, M. S., and Whitlow, S. I.: Complexity of Holocene climate as reconstructed from a Greenland ice core, Science, 270, 1962-1964, 1995.

Oppo, D. W., McManus, J. F., and Cullen, J. L.: Deepwater variability in the Holocene epoch, Nature, 422, 277-278, 2003.

Opsteegh, J. D., Haarsma, R. J., Selten, F. M., and Kattenberg, A.: ECBILT: A dynamic alternative to mixed boundary conditions in ocean models, Tellus, 50A, 348-367, 1998.
Palmer, M. A., Gray, L. J., Allen, M. R., and Norton, W. A.: Solar forcing of climate: model results, Adv. Space Res., 34, 343-348, 2004.

Raynaud, D., Barnola, J.-M., Chappellaz, J., Blunier, T., Indermühle, A., and Stauffer, B.: The ice record of greenhouse gases: a view in the context of future changes, Quat. Sci. Rev., 19, 9-17, 2000.

Renssen, H., Goosse, H., Fichefet, T., and Campin, J.-M.: The 8.2 kyr BP event simulated by a global atmosphere-sea-ice-ocean model, Geophys. Res. Lett., 28, 567-570, 2001.

Renssen, H., Goosse, H., and Fichefet, T.: Modeling the effect of freshwater pulses on the early Holocene climate: the influence of high frequency climate variability, Paleoceanogr., 17, 1020, doi:10.1029/2001PA000649, 2002.

Renssen, H., Goosse, H. Fichefet, T., Brovkin, V. Driesschaert, E., and Wolk, F.: Simulating the Holocene climate evolution at northern high latitudes using a coupled atmosphere-sea iceocean-vegetation model, Clim. Dyn., 24, 23-43, 2005 a.

Renssen, H., Goosse, H., Fichefet, T., Masson-Delmotte, V., and Koç, N.: The Holocene climate evolution in the high-latitude Southern Hemisphere simulated by a coupled atmosphere-sea ice-ocean-vegetation model, Holocene, 15, 951-964, 2005 b.

Renssen, H., Goosse, H., and Fichefet, T.: Contrasting trends in North Atlantic deep-water formation in the Labrador Sea and Nordic Seas during the Holocene, Geophys. Res. Lett., 32(8), L08711, doi:10.1029/2005GL022462, 2005c.

Rind, D.: The sun's role in climate variations, Science, 296, 673677, 2002.

Rind, D., Lean, J., and Healy, R.: Simulated time-dependent climate response to solar radiative forcing since 1600, J. Geophys. Res., 104, 1973-1990, 1999.

Risebrobakken, B., Jansen, E., Andersson, C., Mjelde, E., and Hevrøy, K.: A high-resolution study of Holocene paleoclimatic and paleoceanographic changes in the Nordic Seas, Paleoceanogr., 18, 1017, doi:10.1029/2002PA000764, 2003.

Schaeffer, M., Selten, F. M., and Opsteegh, J. D.: Shifts of means are not a proxy for changes in extreme winter temperatures in climate projections, Clim. Dyn., 25, 51-63, 2005.

Schaeffer, M., Selten, F.M., Opsteegh, J.D., and Goosse, H.: Intrinsic limits to predictability of abrupt regional climate change in IPCC SRES scenarios, Geophys. Res. Lett., 29, 1767, DOI 10.1029/2002GL015254, 2002.

Shindell, D. T., Rind, D., Balachandran, N., Lean, J., and Lonergan, P.: Solar cycle variability, ozone, and climate, Science, 284, 305308, 1999.

Shindell, D. T., Schmidt, G. A., Mann, M. E., Rind, D., and Waple, A.: Solar forcing of regional climate change during the Maunder Minimum, Science, 294, 2149-2152, 2001.

Stuiver, M., Reimer, P. J., Bard, E., Beck, J. W., Burr, G. S., Hughen, K. A., Kromer, B., McCormac, G., Van der Plicht, J., and Spurk, M.: INTCAL98 radiocarbon age calibration, 24,000-0 cal BP, Radiocarbon, 40, 1041-1083, 1998.

van der Schrier, G., Weber, S. L., and Drijfhout, S. S.: Sea level changes in the North Atlantic by solar forcing and internal variability, Clim. Dyn., 19, 435-447, 2002.

van Geel, B. and Renssen, H.: Abrupt climate change around 2,650 BP in North-West Europe: evidence for climatic teleconnections and a tentative explanation, in: Water, environment and society in times of climatic change, edited by: Issar, A. S. and Brown, 
N., Kluwer, Dordrecht, pp. 21-41, 1998.

van Geel, B., Buurman, J., and Waterbolk, H. T.: Archaeological and palaeoecological indications of an abrupt climate change in The Netherlands, and evidence for climatological teleconnections around 2650 BP, J. Quat. Sci., 11, 451-460, 1996.

van Geel, B., van der Plicht, J., Kilian, M. R., Klaver, E. R., Kouwenberg, J. H. M., Renssen, H., Reynaud-Farrera, I., and Waterbolk, H. T.: The sharp rise of ${ }^{14} \mathrm{C}$ around $800 \mathrm{cal} \mathrm{BC}$ : possible causes, related climatic teleconnections and the impact on human environments, Radiocarbon, 40, 535-550, 1998.

van Geel, B., Heusser, C. J., Renssen, H., and Schuurmans, C. J. E.: Climate change in Chile at around $2700 \mathrm{BP}$ and global evidence for solar forcing: a hypothesis, Holocene, 10, 659-664, 2000.

Vonmoos, M., Beer, J., and Muscheler, R.: Large variations in Holocene solar activity - constraints from 10Be in the GRIP ice core, J. Geophys. Res. - Space Phys., in press, 2006.
Wang, Y. M., Lean, J. L., and Sheeley, N. R.: Modeling the sun's magnetic field and irradiance since 1713, Astrophys. J., 625, 522-538, 2005.

Weber, S. L., Crowley, T. J., and van der Schrier, G.: Solar irradiance forcing of centennial climate variability: linear and nonlinear responses in a coupled model, Clim. Dyn., 22, 539-553, 2004.

Wiersma, A. P. and Renssen, H.: Model-data comparison for the 8.2 ka BP event: confirmation of a forcing mechanism by catastrophic drainage of Laurentide Lakes, Quat. Sci. Rev., 25, 63-88, 2006.

Yang, S., Odah, H., and Shaw, J.: Variations in the geomagnetic dipole moment over the last 12000 years, Geophys. J. Int., 140, 158-162, 2000. 